\title{
小青竜湯と麦門冬湯の好酸球生存 および脱顆粒に対する効果
}

\author{
大久保喜雄＼cjkstart関口 守衛
}

\begin{abstract}
要旨 我々は in vitro で小青竜湯および麦門冬湯の好酸球への生存率および脱顆粒への 効果につき検討した。ヒト好酸球を種々の濃度の小青竜湯抢よび麦門冬湯と recombinant human interleukin-5 (rhIL-5) 存在下 $(100 \mathrm{pg} / \mathrm{m} \ell)$ 抢よび非存在下で $37^{\circ} \mathrm{C}, 5 \% \mathrm{CO}_{2} 95 \%$ air 条件下で培羑し，4 日後に好酸球の生存率を算定した。

小青竜湯および麦門冬湯両者は $1000 \mu \mathrm{g} / \mathrm{m}$ のの濃度で有意に好酸球の生存率を抑制した（それ ぞれ $\mathrm{p}<0.05)$ ・脱顆粒の測定のため, 七ト好酸球を種々の濃度の小青竜湯および麦門冬湯と 15 分間 $37^{\circ} \mathrm{C}, 5 \% \mathrm{CO}_{2} 95 \%$ air 存在下で培養し, さらにその後卵白アルブミン (OVA), ヒト 免疫グロブリン G (hIgG) またはヒト分泌型免疫グロブリン A (hsIgA）でコーティングした sepharose $4 \mathrm{~B}$ と 4 時間培養した。その後培養上清を採取してラジオイムノアッセイにより好 酸球の脱顆粒を示す eosinophil cationic protein の量を測定した。OVA，hIgG および hsIgA による好酸球の脱顆粒は小青竜湯（それぞれ $40 \mu \mathrm{g} / \mathrm{m} \ell, \quad \mathrm{p}<0.05 ; 200 \mu \mathrm{g} / \mathrm{m} \ell, \quad \mathrm{p}<$ $0.05 ; 200 \mu \mathrm{g} / \mathrm{m} \ell, \quad \mathrm{p}<0.05 ）$ により有意に抑制された。OVA による好酸球の脱顆粒は麦門 冬湯 $(1000 \mu \mathrm{g} / \mathrm{m} \ell, \mathrm{p}<0.05)$ により有意に抑制された。これらの結果はさらに研究が必要で あるが小青竜湯および麦門冬湯の両者のうち特に小青竜晹はアレルギーの治療に対して有用で ある可能性があることを示唆する。
\end{abstract}

\section{緒 言}

好酸球は気管支喘息を始め各種のアレルギーに 抢いて重要な役割をしている。好酸球の免疫生物 学的機能としてはサイトカイン存在下で好酸球の

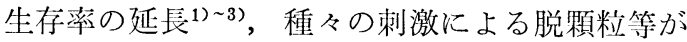
報告されている(4)5)。そこで今回小青竜湯および 麦門冬湯を用いて好酸球の生存率扣よび脱顆粒に 対する効果をin vitro で検討した。

\section{方 法}

ヘパリン添加ヒト末梢血を $6 \%$ dextran (Pharmacia Fine Chemicals, Uppsala, Swe- den）に $5: 1$ の割合で混合し， 45 分間 $37^{\circ} \mathrm{C}$ にて 静置した。白血球を含む上清を採取し， $200 \mathrm{~g}$ で 遠心後, percoll (Sigma Chemical Co., MO, USA）不連続勾配層〔それぞれの比重：1.120 $(0.4 \mathrm{~m} \ell), 1.100(3 \mathrm{~m} \ell), 1.090(3 \mathrm{~m} \ell), 1.085$ $(3 \mathrm{~m} \ell), 1.080(3 \mathrm{~m} \ell)]$ を作成し, 上層に比重 1. 070の percoll に浮遊した白血球檿 $(2 \mathrm{~m} \ell)$ を 乗せ， $1,500 \mathrm{~g}, 45$ 分間， $4{ }^{\circ} \mathrm{C}$ で遠心し，比重1.095 以上の normodense の好酸球を採取した。

1) 好酸球の生存率

基礎实験として各濃度の recombinant human interleukin 5 (rhIL-5, Shering Co., NJ, USA) 存在下の好酸球の生存率を検討した。その結果

医，倩州大学第 1 内科，辰野 


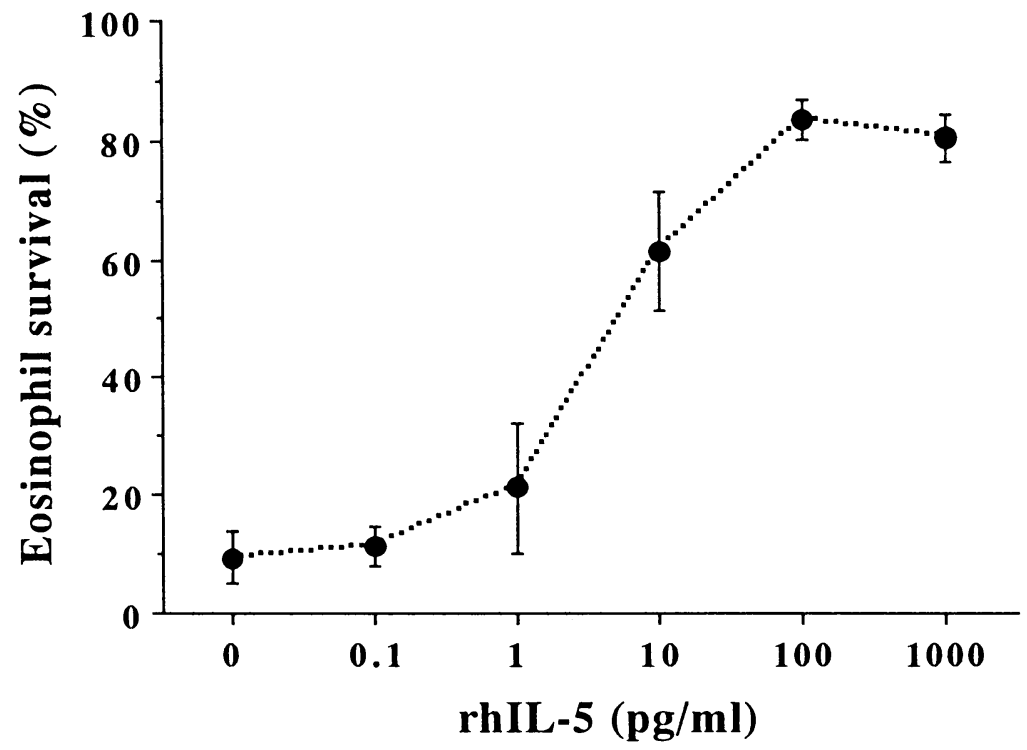

図 1 各種濃度の rhIL-5 存在下での好酸球の生存率 $(n=5)$

rhIL-5 の濃度が $100 \mathrm{pg} / \mathrm{m} \ell$ で plateau となる 好酸球の生存率を示した(図 1)。以後この基礎実 験と同じ条件下に扣いてッムラ小青竜湯エキス原 末 (lot. 920019001p5; 組成; 半夏, 甘草, 桂皮, 五味子, 細辛, 药薬, 麻黄, 乾美) 扎よびッムラ 麦門冬湯エキス原末 (lot. 900029001p1；麦門冬， 半夏, 大東, 甘草, 人参, 糠米) の好酸球の生存 率に対する効果を検討した。即ち $10 \%$ defined calf serum (Hyclone Laboratories Inc., UT, USA), gentamicin $(50 \mu \mathrm{g} / \mathrm{m} \ell), 0.1 \%$ human serum albumin (Sigma Chemical Co., MO, USA), L-glutamine (2mM, Sigma Chemical Co., MO, USA)を添加した hybri-care medium (American Type Culture Collection, MD, USA）に好酸球 $\left(2.5 \times 10^{5} / \mathrm{m} \ell\right)$ を浮遊させた。 小青竜湯 $5 \mathrm{~g}$ および麦門冬湯 $5 \mathrm{~g}$ を蒸留水 $5 \mathrm{~m} \ell$ （各々の濃度 $1 \mathrm{~g} / \mathrm{m} \ell$ ) に溶解し voltexにより十分 擋拌した。その後 $800 \mathrm{~g} 10$ 分間遠心後沈渣が混入 しないよう注意深く上清を採取後小青竜湯および 麦門冬湯それぞれの溶解液を培養液で希釈して最 終濃度を $1,000 \mu \mathrm{g} / \mathrm{m} \ell, 200 \mu \mathrm{g} / \mathrm{m} \ell, 40 \mu \mathrm{g} / \mathrm{m} \ell$ に 調整して half area tissue culture plate ( $\# 3696$, Costar, MA, USA) に分注し, 好酸球 (2.5× $10^{4} /$ well）と 15 分間 $37^{\circ} \mathrm{C}, 5 \% \mathrm{CO}_{2} 95 \%$ air 存在
下で培盖した。その後最終濃度として $100 \mathrm{pg} / \mathrm{m} \ell$ および $0 \mathrm{pg} / \mathrm{m} \ell$ の $\mathrm{rhIL}-5$ で全量を $100 \mu \ell$ とし て,さらに 4 日間培養した。好酸球の生存率は fluorescein diacetate ${ }^{6)}$ (Sigma Chemical Co., MO, USA）を用いて萤光顕微鏡下で次式のよう にして算定した。

好酸球の生存率＝生存している好酸球／全細胞 数 $\times 100$

2 ）好酸球の脱顆粒

好酸球の脱顆粒に対する効果の検討は既に報告 された方法に準じて行っだ)。即ち小青竜湯およ び麦門冬湯（それぞれ最終濃度 $1,000 \mu \mathrm{g} / \mathrm{m} \ell, 200$ $\mu \mathrm{g} / \mathrm{m} \ell, 40 \mu \mathrm{g} / \mathrm{m} \ell)$ と好酸球 $\left(2.5 \times 10^{5}: 100 \mu \ell\right)$ を microtissue culture plate ( $\# 3072$, Falcon, CA, USA)で15分間培養した。さらに ovalbumin (OVA, Sigma Chemical Co., MO, USA), human IgG (hIgG, Organon Teknika-Cappel, PA，USA)， あるいは human secretory-IgA (hsIgA, Accurate Chemical Scientific Corporation, NY, USA) で coating した sepharose $4 \mathrm{~B}(50 \mu \ell)$ を好酸球と20：1の比に合わせ全量 を $200 \mu \ell$ としさらに 1 時間培養した。その後，4 ${ }^{\circ} \mathrm{C}, 1,000 \mathrm{~g}$ で遠心して上清を採取して脱顆粒の 指標として eosinophil cationic protein (ECP) 
を RIA キット (Pharmacia Fine Chemicals, Uppsala, Sweden）を用いて测定した。脱顆粒の 抑制率は次式により算定した。

脱顆粒の抑制率 $=($ 薬剂無添加の ECP 濃度一薬 剂添加の ECP 濃度) / 薬剂無添加の ECP 濃度 $\times 100$

\section{3 ) 統計的検討}

結果は Mean \pm SEM で示し, 有意差検定は Student's paired t-test を用いて検討した。

\section{結 果}

小青堂晹括よび麦門冬湯添加洔の好酸球の生存 率をそれぞれ図 2 と図 3 亿示した。100 pg/m / の rhIL-5 存在下に打壮る小青竟湯 $1,000 \mu \mathrm{g} / \mathrm{m} \ell$ 打よ び $0 \mu \mathrm{g} / \mathrm{m} \ell$ での好陵球の生存率は $80.5 \pm 4.4 \%$ 少 よび $89.8 \pm 2.0 \%$ でり，小青竜湯 $1,000 \mu \mathrm{g} / \mathrm{m} \ell$ において明らかな抑制を楒めた $(\mathrm{p}<0.05)$ 。し かし, rhIL-5 非存在下の小青竜湯 $1,000 \mu \mathrm{g} / \mathrm{m} \ell$ $(3.2 \pm 1.3 \%)$ および $0 \mu \mathrm{g} / \mathrm{m} \ell(6.5 \pm 1.6 \%) の$ 两者間に打いては好酸球の生存率には有意差を認 めなかった。 $100 \mathrm{pg} / \mathrm{m} \ell$ の rhIL-5 存在下に出け る麦門冬湯 $1,000 \mu \mathrm{g} / \mathrm{m} \ell$ および $0 \mu \mathrm{g} / \mathrm{m} \ell$ での好 酸球の生存率は $89.6 \pm 1.6 \%$ および $95.1 \pm 1.1 \%$ で あり，麦門冬湯 $1,000 \mu \mathrm{g} / \mathrm{m} \ell$ の濃度において明ら

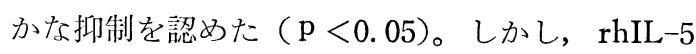
非存在下に括いては麦門冬湯 $1,000 \mu \mathrm{g} / \mathrm{m} \ell(4.3$ $\pm 1.8 \%)$ 拈よび $0 \mu \mathrm{g} / \mathrm{m} \ell(7.9 \pm 4.0 \%)$ の雨者間 では好酸球の生存率には有意差を垫めなかった。

小青竜湯打よび麦門冬湯による好酸球の脱顆 粒の抑制を図 4 と図 5 に示した。小青竜湯では OVA による脱顆粒に対する抑制率は $1,000 \mu \mathrm{g} /$ $\mathrm{m} \ell, 200 \mu \mathrm{g} / \mathrm{m} \ell$ 抢よび $40 \mu \mathrm{g} / \mathrm{m} \ell$ に打いて，それ ぞれ $76.6 \pm 7.5 \% ， 61.9 \pm 0.4 \% ， 38.4 \pm 7.7 \%$ で あり，いずれも有意な抑制を認めた（ $\mathrm{p}<0.001$, $\mathrm{p}<0.05, \mathrm{p}<0.05)$ 。

$\mathrm{hIgG}$ による抑制率は $1,000 \mu \mathrm{g} / \mathrm{m} \ell$ および 200 $\mu \mathrm{g} / \mathrm{m} \ell$ の濃度ではそれぞれ $90.1 \pm 5.0 \%, 25.2 \pm$ $5.2 \%$ あ゙あ，それぞれ有意な抑制を認めた（p $<0.001, \quad \mathrm{p}<0.05)$ 。

hsIgA による脱顆粒の抑制率は $1,000 \mu \mathrm{g} / \mathrm{m} \ell$ お よび $200 \mu \mathrm{g} / \mathrm{m} \ell$ の濃度ではそれぞれ $70.7 \pm 7.2 \%$,

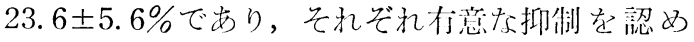
た $(\mathrm{p}<0.001, \mathrm{p}<0.05)$ 。

麦門冬晹の OVAによる脱顆粒に対する抑制率 は $1,000 \mu \mathrm{g} / \mathrm{m} \ell$ に抢いては28.8土10.0\%であり有

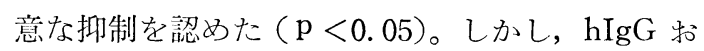
よび hsIgA による好酸球の脱颗粒に刘しては有 意な抑制を認めなかった。

\section{考 案}

现在，アレルギー疾患の 1 つである気管支喘息 は炎症疾患であることが浔められている7 。一力， 好酸球の脱颗精により放出される好陵球内の蛋 ウである major basic protein (MBP), ECP, eosinophil derived neurotoxin (EDN) は気管 支上皮の傷害, 気道の過敏性の直進, 把満絸狍や 好塩基球からのメディエーター遊離捉進, 気管支 平滑筋の収縮を葆起する等8) 12) 気管支喘息の病 態に重要な役割を果している。好陵球は rhIL-5 の存在下でその生存が延長されることは既に報告 されている ${ }^{3)}$ 。そこで小青竜湯打よび麦門冬晹の rhIL-5 存在下の好酸球生存に対する効果をin vitro で検封したところ雨者とも $1,000 \mu \mathrm{g} / \mathrm{m} \ell て ゙$ 好酸球の生存を抑制した。しかし rhIL-5 非存在 下では両者とも好酸球の生存を抑制しなかったこ とより $\mathrm{rhIL}-5(100 \mathrm{pg} / \mathrm{m} \ell)$ 存在下での小青竜湯 および麦門冬晹 $(1,000 \mu \mathrm{g} / \mathrm{m} \ell)$ の効果は雨薬剂に よる特異的な抑制反応と思われる。

一方，好酸球の脱顆粒に刘する小青竜湯および 麦門冬湯の効果は，小青竜晹では OVA，hIgG および hsIgA による脱顆粒効果はいずれに対し ても比較的低濃度で抑制したが，肯門冬晹では皿 濃度でしかも OVAによる脱顆䊉に対してのみ抑 例が垫められた。好酸球の OVA, hIgG, hsIgA による脱顆粒执よび好陵球の牛存のメカニズムに ついては明らかではないが，好陵球上の受容休拉 よび細胞内状報伝達機構の暹い等も考光られ，さ らに検討を要する。

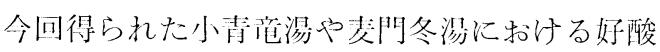
球の生存延長の抑制作用や小青意演の此較的低濃 度での好酸球の脱顆粘の抑制作用は父管支喘息を 始め好酸球が增加するアレルギー疢患の治療に存 


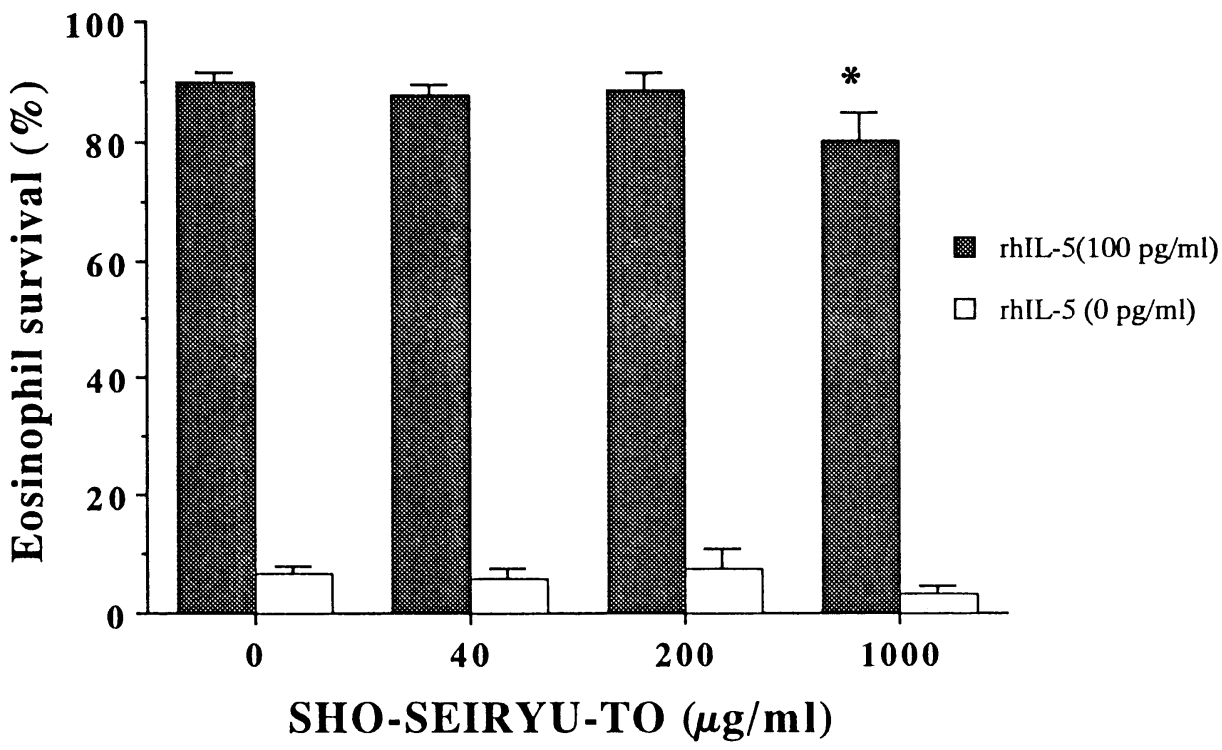

図2 小青竜湯の好酸球の生存に対する効果 $(n=4)$

*:p $<0.05 \mathrm{rhIL}-5(100 \mathrm{pg} / \mathrm{m} \ell)$ 存在下の小青竜湯 $1000 \mu \mathrm{g} / \mathrm{m} \ell$

の好酸球の生存率之 $0 \mu \mathrm{g} / \mathrm{m} \ell$ の好酸球の生存率之の比較

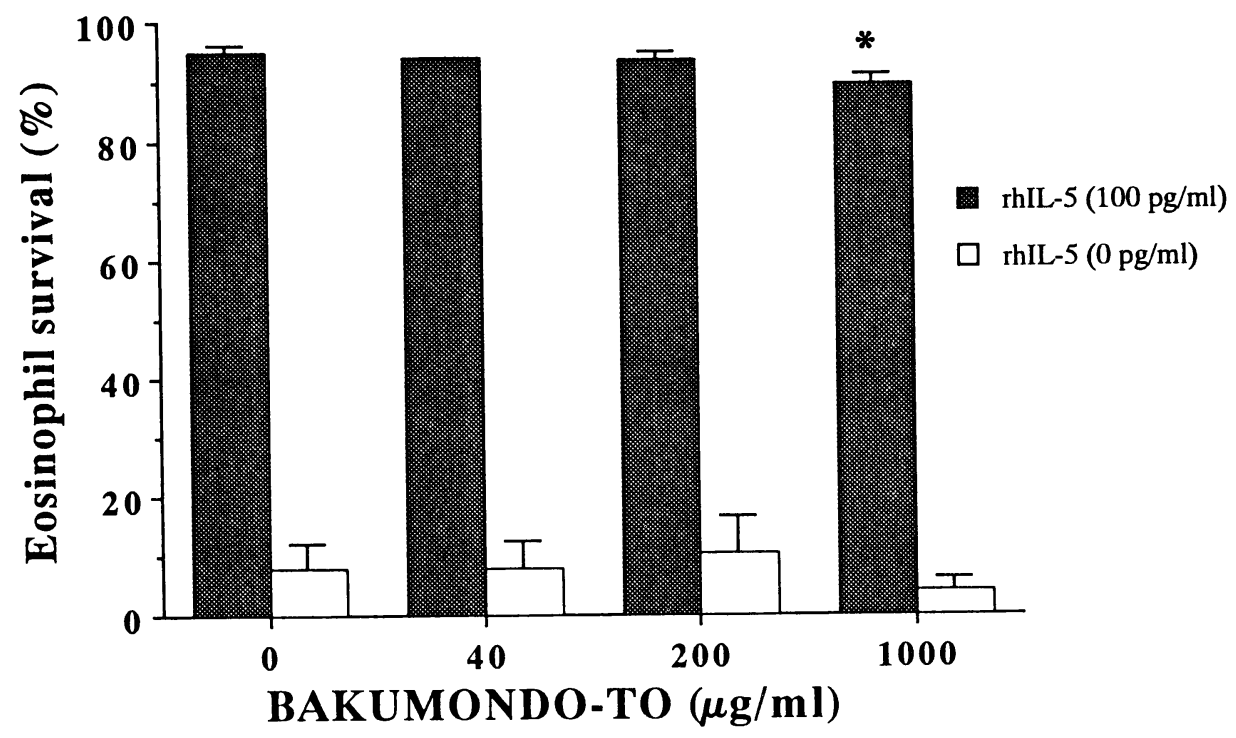

図 3 麦門冬湯の好酸球の生存に対する効果 $(n=3)$

$*: \mathrm{p}<0.05 \mathrm{rhIL}-5(100 \mathrm{pg} / \mathrm{m} \ell)$ 存在下の考阿冬湯 $1000 \mu \mathrm{g} / \mathrm{m} \ell$ の好酸球の生存率と $0 \mu \mathrm{g} / \mathrm{m} \ell$ の好酸球の生存摔との比較

用である可能性を示唆するものでこれからの研究 に期待したい。
結 語

小青龟湯就よび麦門冬湯の好酸球の生存および 


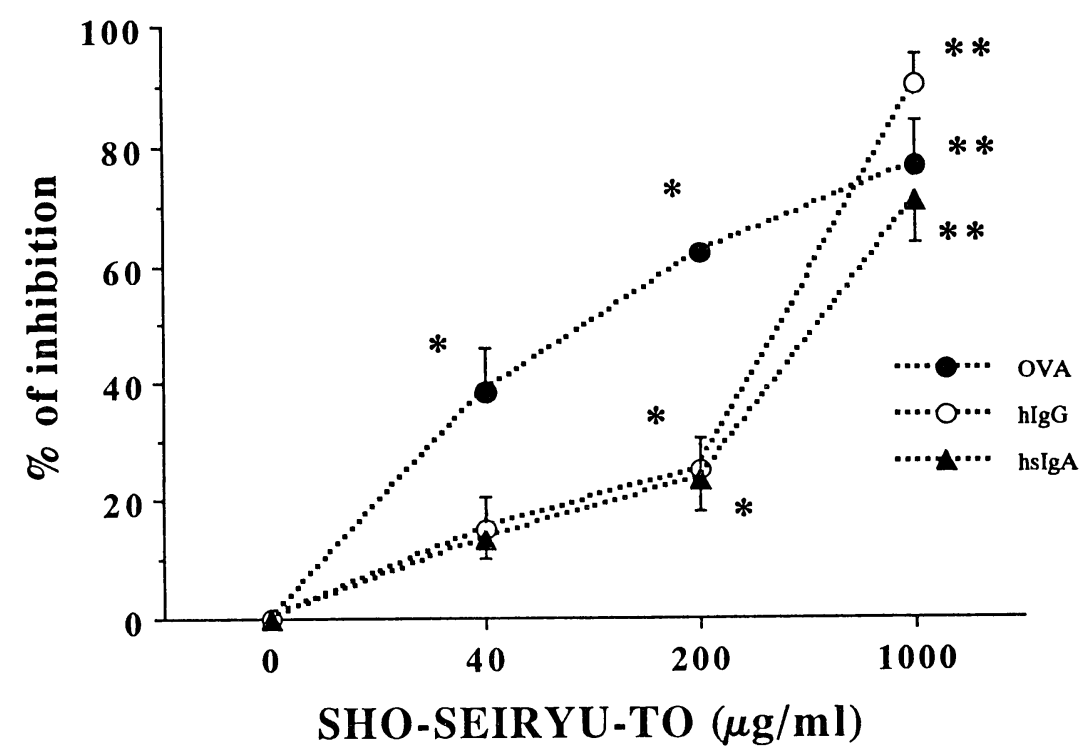

図 4 小青竞湯の好酸球の脱顆粒に刘する効果 $(\mathrm{n}=4)$ ${ }^{*}: \mathrm{p}<0.05^{* *}: \mathrm{p}<0.001$ 各濃度の小洁意晹の抑制摔と $0 \mu \mathrm{g} / \mathrm{m} \ell$ の小青竞晹の抑制率との比恔

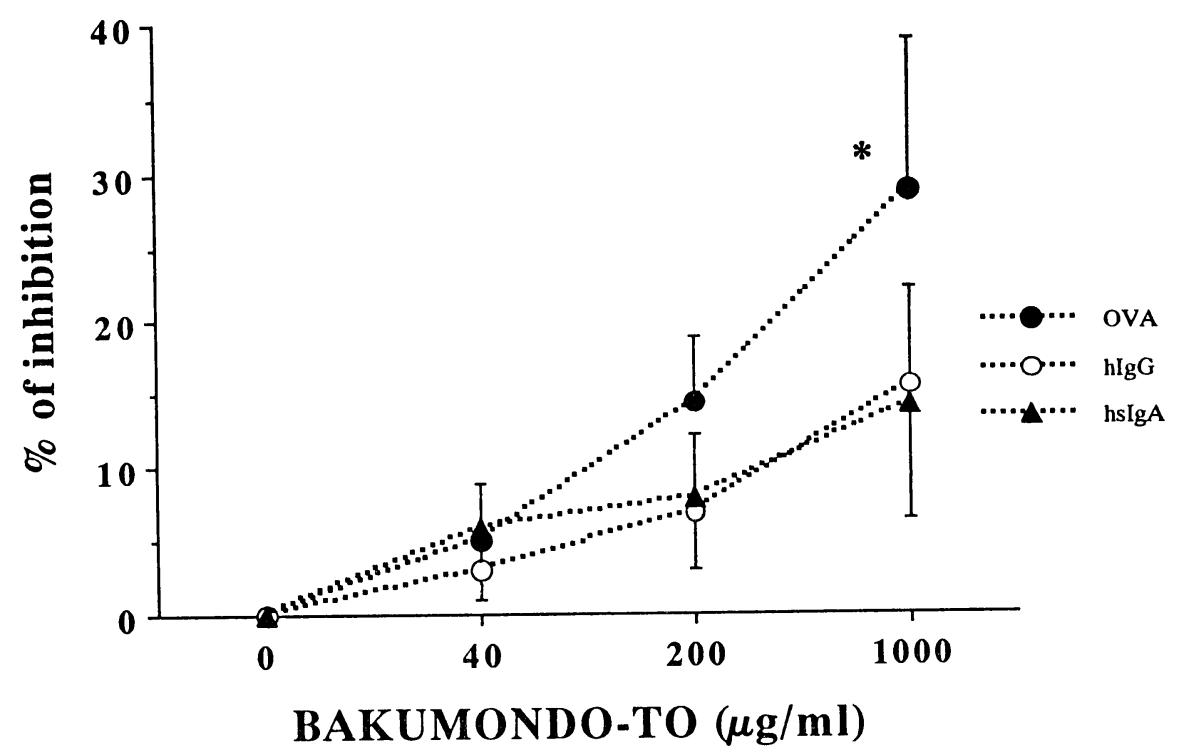

图 5 责門冬晹の好酸球の脱颗粒に刘する效果 $(\mathrm{n}=4)$ ${ }^{*}: \mathrm{p}<0.05$ 各旅度の考梐冬湯の抑例摔と $0 \mu \mathrm{g} / \mathrm{m} \ell$ の麦 閅冬湯の抑例摔之の比校

脱顆粒につき検封して以下の絬果を得た。 rhIL-5 ( $100 \mathrm{pg} / \mathrm{m} \ell)$ の存在下で小青部湯拈よ

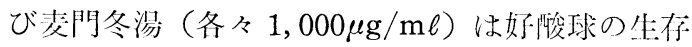

率を抑例した。

小责栄晹に上る好酸球の航颗粒の抑制は OVA では $40 \mu \mathrm{g} / \mathrm{m} \ell, \mathrm{hIgG}$ 拈よび hsIgA では $200 \mu \mathrm{g}$ 
$/ \mathrm{m} \ell$ 以上の濃度で有意であった。麦門冬晹の好俟 球の脱顆粒の抑制は OVA の場合のみ珰められ， その濃度は $1,000 \mu \mathrm{g} / \mathrm{m} \ell$ であった。

本論文の主旨は第44回日本束压医学会学術総会（仙 台，1993年 6 月）において発表した。

\section{文 献}

1 ) Rothenberg, M. E., et al.: Human eosinophils have prolonged survival, enhanced functional properties, and become hypodense when exposed to human interleukin 3 , J. Clin. Invest., $\mathbf{8 1}$, p.1986, 1988

2) Lopez, A. F., et al.: Recombinant human granulocyte-macrophage colony-stimulating factor stimulates in vitro mature human neutrophil and eosinophil function, surface expres sion, and survival, J. Clin. Invest., 78, p.1220, 1986

3) Rothenberg, M. E., et al.: IL-5 dependent conversion of normodense human eosinophils to the hypodense phenotype uses 3T3 fibroblasts for enhanced viability, accelerated hy podensity, and sustained antibody dependent cytotoxicity, J. Immunol., 143, p.2311, 1989

4) Abu-Ghazaleeh, R. I., et al.: IgA-induced eosinophil degranulation, J. Immunol., 142, p.2393, 1989

5 ) Fujisawa, T., et al.: Regulatory effect of cytokines on eosinophil degranulation, J. Immunol., 144, p.642, 1990

6) Kita, H., et al. : Granulocyte/macrophage colony-stimulating factor and interleukin 3 release from human peripheral blood eosinophils and neutrophils, J. Exp. Med., 174, p.745, 1991

7 ) American Thoracic Society Standards for the diagnosis and care of patients with chronic obstructive pulmonary disease and asthma, Am. Rev. Respir. Dis., 136, p.225, 1987

8 ) Frigas, E., et al.: The eosinophil and the pathophysiology of asthma, J. Allergy. Clin. Immunol., 77, p.527, 1986

9) Gleich, G. J.: The eosinophil and bronchial asthma:current understanding. J. Allergy. Clin. Immunol., 85, p.422, 1990

10) Motojima, S., et al.: Toxicity of eosinophil cationic proteins for guinea pig trachial epithelium in vitro, Am. Rev. Respir. Dis., 139, p.801, 1989

11) Gundel, R. H., et al.: Human eosinophil major basic protein induces airway constriction and airway hyperresponsiveness in primates, J. Clin. Invest., 87, p.1470, 1991

12) White, S. R., et al.: Epithelium-dependent constraction of airway smooth muscle caused by eosinophil MBP, Am. J. Physiol., 259, p. L 294, 1990

（1993年11月11日受理）

\section{Abstract \\ Effects of Sho-seiryu-to and Bakumondo-to on Human Eosinophil Viability and Degranulation in vitro.}

\section{Yoshio Oкubo Morie Sekiguchi}

Shinshu University, School of Medicine, lst Department of Internal Medicine

We examined the effect of Sho-seiryu-to and Bakumondo-to on eosinophil viability and degranulation in vitro. Human eosinophils were cultured at various concentrations of Sho-seiryu-to and Bakumondo-to with or without recombinant human interleukin- 5 $(\mathrm{rhIL}-5,100 \mathrm{pg} / \mathrm{m} \ell)$ at $37^{\circ} \mathrm{C}, 5 \% \mathrm{CO}_{2} 95 \%$ air and the eosinophil viability was measured on day four. Both Sho-seiryu-to and Bakumondo-to significantly reduced eosinophil viability at a concentration of $1,000 \mu \mathrm{g} / \mathrm{m} \ell(\mathrm{p}<0.05, \mathrm{p}<0.05$, respectively). For degranulation assay, human eosinophils were cultured with various concentrations of 
Sho-seiryu-to and Bakumondo-to for $15 \mathrm{~min}$ at $37^{\circ} \mathrm{C}, 5 \% \mathrm{CO}_{2} 95 \%$ air and then further cultured with ovalbumin (OVA), human immunoglobulin $\mathrm{G}$ (hIgG) or human secretory $\operatorname{Ig} \mathrm{A}$ (hsIgA)-coated sepharose 4B for four hours. The culture supernatants were collected and the contents of essinophil cationic protein (ECP), indicating eosinophil degranulation, were measured by radioimmunoassay. Eosinophil degranulation induced by OVA, hIgG and hsIgA was significantly inhibited by Sho-seiryu-to $(40 \mu \mathrm{g} / \mathrm{m} \ell, \mathrm{p}<0.05 ; 200 \mu \mathrm{g} / \mathrm{m} \ell, \mathrm{p}<0.05$ and $200 \mu \mathrm{g} / \mathrm{m} \ell, \mathrm{p}<0.05$, respectively). OVAinduced eosinophil degranulation was significantly inhibited by Bakumondo-to (1,000 $\mu \mathrm{g} / \mathrm{m} \ell, \mathrm{p}<0.05)$. These results suggest that Sho-seiryu-to and Bakumondo-to, especially the former, may be useful in the treatment of allergy, though further studies are needed. 